\title{
Potential impact of climate change on improved and unimproved water supplies in Africa
}

\author{
Helen C. Bonsor ${ }^{a}$, Alan M. MacDonald ${ }^{a}$ and Roger C. Calow ${ }^{b}$ \\ ${ }^{a}$ British Geological Survey, West Mains Road, Edinburgh, UK, EH9 3LA \\ ${ }^{b}$ Overseas Development Institute, Westminster Bridge Road, London, UK, SE1 7JD \\ Corresponding author: helnso@bgs.ac.uk
}

\begin{abstract}
With significant climate change predicted in Africa over the next century, this chapter explores a key question: how will rural water supplies in Africa be affected? Approximately 550 million people in Africa live in rural communities and are reliant on water resources within walking distance of their community for drinking water. Less than half have access to improved sources (generally large diameter wells, springs, or boreholes equipped with handpumps); the majority rely on unimproved sources, such as open water and shallow wells. Major climate modelling uncertainties, combined with rapid socio-economic change, make predicting the future state of African water resources difficult; an appropriate response to climate change is to assume much greater uncertainty in climate and intensification of past climate variability. Based on this assumption the following should be considered:
\end{abstract}

1. Those relying on unimproved water sources (300 million in rural Africa) are likely to be most affected by climate change because unimproved sources often use highly vulnerable water resources.

2. Improved rural water supplies in Africa are overwhelmingly dependent on groundwater, due to the unreliability of other sources.

3. Climate change is unlikely to lead to continent-wide failure of improved rural water sources that access deeper groundwater (generally over 20 metres below ground surface) through boreholes or deep wells. This is because groundwater-based domestic supply requires little recharge, and the groundwater resources at depth will generally be of sufficient storage capacity to remain a secure water resource. However, a significant minority of people could be affected if the frequency and length of drought increases particularly those in areas with limited groundwater storage.

4. In most areas, the key determinants of water security will continue to be driven by access to water rather than absolute water availability. Extending access, and ensuring that targeting and technology decisions are informed by an understanding of groundwater conditions, will become increasingly important.

5. Accelerating groundwater development for irrigation could increase food production, raise farm incomes and reduce overall vulnerability. However, ad hoc development could threaten domestic supplies and, in some areas, lead to groundwater depletion.

Although climate change will undoubtedly be important in determining future water security, other drivers (such as population growth and rising food demands) are likely to provide greater pressure on rural water supplies. 


\section{Table of contents}

1 Introduction

2 Scenarios of Climate Change

2.1 IPCC Fourth Assessment of Climate Change

2.2 Key Uncertainties in Climate Projections

2.3 Projected Climate Change in Africa

2.4 Climate Change since the IPCC Fourth Assessment: $4{ }^{\circ} \mathrm{C}$ Possibilities

2.5 Summary

3 Impacts of Climate Change on Rural Water Supply in Africa

3.1 A Framework for Discussion

3.2 Likely Impact of Climate Change on Available Water Resources

3.3 Access to Reliable Water Supplies

3.4 Changing Water Demands

4 Summary 


\section{Introduction}

There is growing concern that climate change will have greatest impact on the world's poorest and most vulnerable people. The poor often have few options of where to access food and water and are highly reliant on the natural resources found close to their home and community. One group perceived to be highly vulnerable are the rural poor in Africa. With climate predicted to change significantly over the continent in the next century, this chapter explores the key question: how will rural water supplies be affected?

There are few large-scale public water supplies in rural Africa and, as a result, rural communities (some 550 million people in total) are generally reliant on water resources found within walking distance of their homes. The Joint Monitoring Programme ${ }^{1}$ of WHO and UNICEF identifies three categories of drinking water supply: (a) water piped into the dwelling, plot or yard; (b) other improved sources (including public taps, protected springs, handpumps and rainwater harvesting); and (c) unimproved sources (open water, unprotected from contamination). For rural sub-Saharan Africa, 5\% of the population have piped water, $41 \%$ are reliant on other improved sources (mostly wells and boreholes equipped with handpumps) and 54\% (300 million people) have to rely on unimproved sources ${ }^{1}$.

Figure 1 shows examples of the improved water sources typically found across Africa. These commonly exploit groundwater resources through boreholes equipped with a handpump, large diameter wells, or springs ${ }^{2}$. Unimproved sources (on which the majority rely) comprise ponds, small dugouts, streams and commonly handdug wells less than $10 \mathrm{~m}$ deep - see Figure 2. These unimproved supplies often fail in the dry season, resulting in people having to walk longer distances to collect drinking water from more sustainable sources ${ }^{3}$.
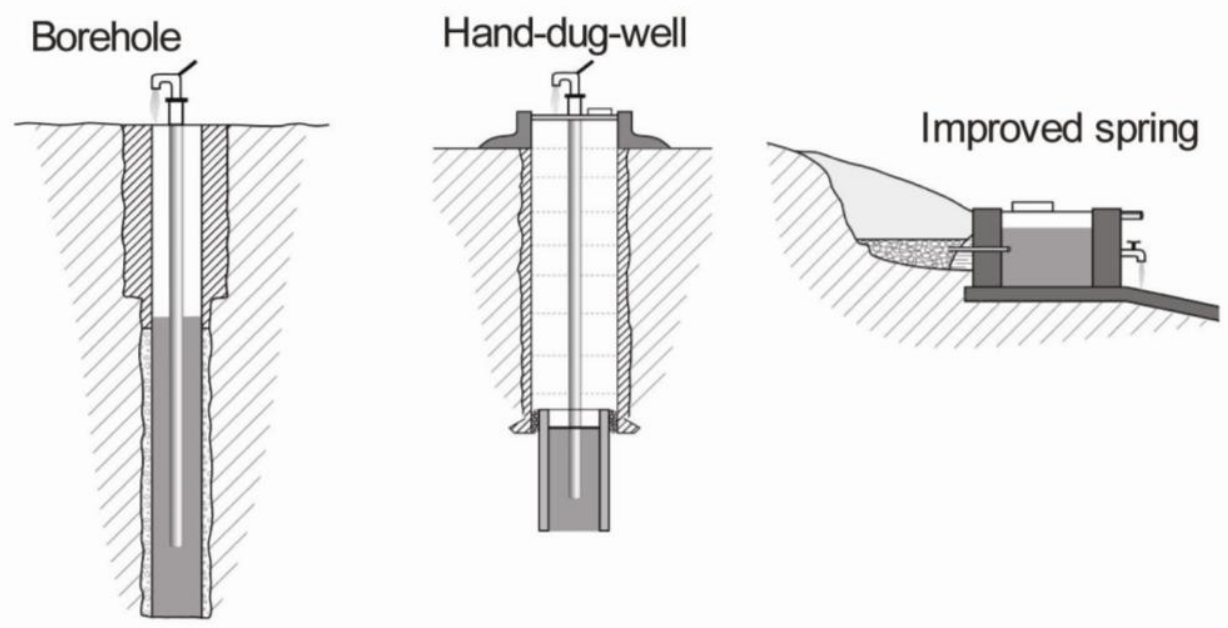

Figure 1 - Most common types of improved rural water supplies within Africa ${ }^{2}$. 

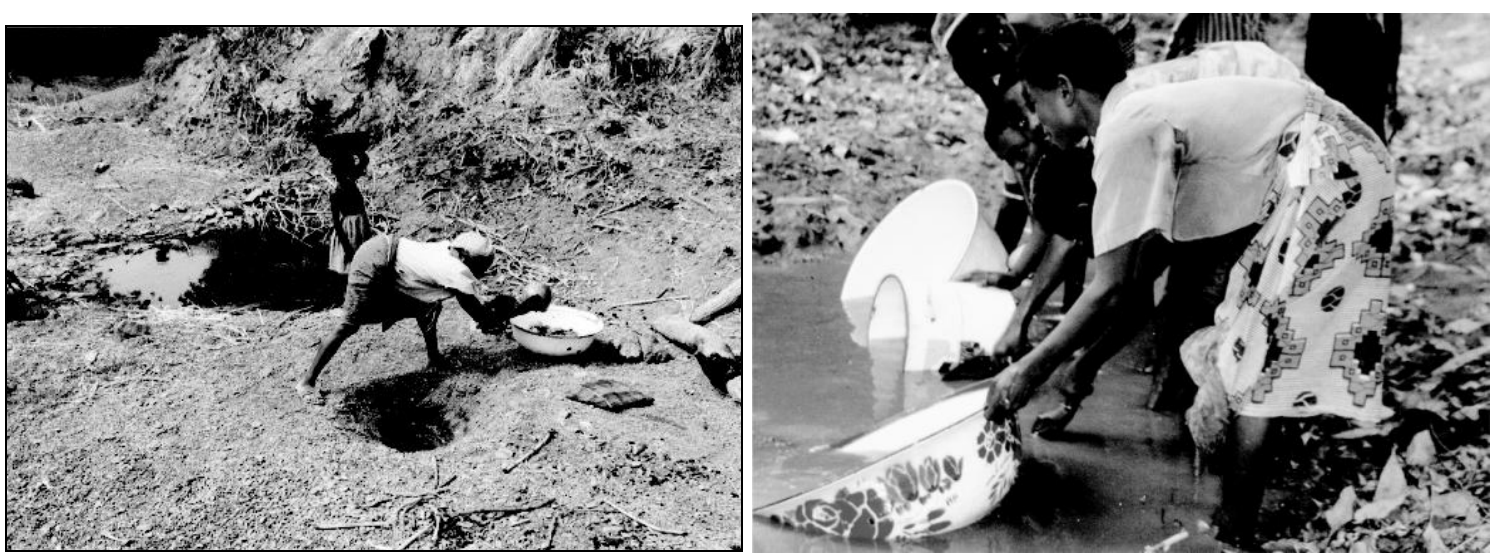

Figure 2 - Unimproved sources are commonly shallow traditional wells (usually less than $10 \mathrm{~m}$ deep) within thick soils, or unprotected surface ponds and seepages (above).

The rise in temperature predicted with climate change will affect water resources and, therefore, all drinking water supplies - but the prediction of impacts is both complex and uncertain ${ }^{4}$. With such uncertainty there is a high risk that policies are introduced and practices adopted which are inappropriate, that could actually reduce water security ${ }^{3}$. To help reduce uncertainty, experience of water usage and water source behaviour during droughts in Africa is used to help understand the likely impacts of a changing climate ${ }^{5}$. These interdisciplinary studies indicate that water security is determined by three factors: absolute water resource availability, access to these water resources and changing water demand and use. By understanding the interplay between these three factors more reliable predictions can be made and policies developed which are more likely to reflect best options in future decades.

\section{Scenarios of Climate Change}

Warming of the climate, by whatever means, is now unequivocal, with recorded increases since 1960 of global mean air temperature $\left(c .+1{ }^{\circ} \mathrm{C}\right)$, sea surface temperature $\left(c .+1{ }^{\circ} \mathrm{C}\right)$ and sea level rise $(c .+150 \mathrm{~mm})^{4}$. With continued population growth and increased global economic development, climate change is predicted to occur at a much faster rate over the next 50 years and there is a growing body of evidence that a global mean temperature rise of $2.4^{\circ} \mathrm{C}$ will occur by 2100 regardless of any future emissions cuts ${ }^{6,7}$. Within Africa, such climate change is likely to cause a $3-4{ }^{\circ} \mathrm{C}$ rise in land-surface temperature and an intensification of the existing climatic and hydrological variability ${ }^{8,4}$.

\subsection{IPCC Fourth Assessment of Climate Change}

The Intergovernmental Panel on Climate Change (IPCC) has, in the last 20 years, published several reports synthesising climate change science and the Fourth Assessment (AR4), published in 2007, still provides the 
most comprehensive overview of likely climate change to date. Climate change is predicted by the IPCC based on a series of different emissions scenarios resulting from various lines of global socio-economic development and population growth ${ }^{9,10}$.

Six benchmark scenarios were developed by the Fourth Assessment - A1F1, A1T, A1B, A2, B1 and B2 - which were taken to be representative of the wide range of possible world development pathways and resultant emissions in the next century and to encompass a significant proportion of the underlying uncertainties in the main driving forces of emissions - see Figures 3 and $4^{10}$. Scenarios A1F1 and A1B form the 'worst-case' scenarios with high greenhouse gas emissions over the next century; scenarios B1 and B2 simulate reducing emissions by 2100 , with lower population growth and the development of lower-carbon energy sources. Which scenario is most realistic for future emissions depends critically upon whether economic development remains the dominant global aspiration in the future and whether present socio-economic globalisation will intensify or wane $^{9,10}$ - see Figure 4.

A1 scenario family: a future world of very rapid economic growth, global population that peaks in mid-century and declines thereafter, and rapid introduction of new and more efficient technologies.

A2 scenario family: a very heterogeneous world with continuously increasing global population and regionally oriented economic growth that is more fragmented and slower than in other storylines.

B1 scenario family: a convergent world with the same global population as in the A1 storyline but with rapid changes in economic structures toward a service and information economy, with reductions in material intensity and the introduction of clean and resource-efficient technologies.

B2 scenario family: a world in which the emphasis is on local solutions to economic, social, and environmental sustainability, with continuously increasing population (lower than A2) and intermediate economic development.

Source: Nakicenovic et al. 200010.

Figure 3 - Outline of the main IPCC scenario storylines 


\section{Economic emphasis}

\begin{tabular}{|c|c|}
\hline $\begin{array}{l}\text { A1 scenario } \\
\text { World: market-oriented } \\
\text { Economy: fastest per capita growth } \\
\text { Population: } 2050 \text { peak, then decline } \\
\text { Governance: strong regional interactions; } \\
\text { income convergence } \\
\text { Technology: three scenario groups: } \\
\text { A1Fl: fossil intensive } \\
\text { - A1T: non-fossil energy sources } \\
\text { - A1B: balanced across all sources }\end{array}$ & $\begin{array}{l}\text { A2 scenario } \\
\text { World: differentiated } \\
\text { Economy: regionally oriented; lowest per } \\
\text { capita growth } \\
\text { Population: continuously increasing } \\
\text { Governance: self-reliance with } \\
\text { preservation of local identities } \\
\text { Technology: slowest and most } \\
\text { fragmented development }\end{array}$ \\
\hline $\begin{array}{l}\text { B1 scenario } \\
\text { World: convergent } \\
\text { Economy: service and information based; } \\
\text { lower growth than A1 } \\
\text { Population: same as A1 } \\
\text { Governance: global solutions to economic, } \\
\text { social and environmental sustainability } \\
\text { Technology: clean and resource-efficient }\end{array}$ & $\begin{array}{l}\text { B2 scenario } \\
\text { World: local solutions } \\
\text { Economy: intermediate growth } \\
\text { Population: continuously increasing at } \\
\text { lower rate than A2 } \\
\text { Governance: local and regional solutions } \\
\text { to environmental protection and social } \\
\text { equity } \\
\text { Technology: more rapid than A2; less } \\
\text { rapid, more diverse than A1 or B1 }\end{array}$ \\
\hline
\end{tabular}

Source: Nakicenovic et al. 200010.

Figure 4 - Key differences between the potential 'pathways' of global socio-economic development used in the IPCC AR4 emissions scenarios.

Likely climate change from each of the scenarios is predicted by forcing an ensemble of Global Circulation Models (GCMs) with predicted concentrations of long-lived greenhouse gases (LLGHGs) from the emissions scenarios ${ }^{4,11,12}$. This approach enables differences between the climate projections modelled for each emissions scenario to be quantified and enables clear identification of regions in which there is large uncertainty in projected climate change.

\subsection{Key Uncertainties in Climate Projections}

\subsubsection{General Uncertainties in Climate Projections}

Although climate projections are used to drive many adaptation and development discussions, there are significant limitations to the predictive capability of GCMs in assessing likely climate change in many regions worldwide, particularly in data-poor regions such as Africa ${ }^{4}$. Uncertainties in climate modelling are, at least in part, due to the exclusion of several key, but poorly understood feedback processes between global climate and the carbon cycle in current GCMs. Feedback between the climate and carbon cycle is likely to influence significantly how much climate change will result from different levels of emissions. However, our poor understanding of some of these highly complex processes driving land and ocean uptake of carbon means key feedback processes are excluded from most current GCMs. Consequently, many GCMs model future climate change and the global carbon cycle as completely uncoupled systems, so that even feedback effects between 
vegetation and land-use are excluded ${ }^{4}$. The new process-based $C^{4}$ MIP carbon-cycle GCM suite is one of the first attempts to simulate some level of coupling between $\mathrm{CO}_{2}$ loading and the global climate cycle and the results have so far indicated that previous estimates of emissions cuts required to achieve a stabilisation of atmospheric $\mathrm{CO}_{2}$ concentrations in the Earth's atmosphere by 2100 have been conservative ${ }^{13,14}$.

Significant uncertainty in climate change predictions also arises from the underlying uncertainties in the emissions scenarios used to force the climate models and in the assumptions made to simulate physical processes of the climatic system within GCMs. The exclusion of daily or inter-annual climatic variability within GCMs is particularly important, as it is this very short-term climatic variability which is thought to be highly important in simulating the effect of intense rainfall events and the future frequency of droughts.

\subsubsection{Uncertainties in African Climate Projections}

The margin of error in climate predictions for Africa is large: up to $90 \%$ of current GCMs cannot replicate accurately past or present climatic conditions observed within large parts of Africa - particularly in sub-Saharan Africa. Such large errors in the climate models suggest important climatic processes are not being modelling within the GCMs ${ }^{4}$. Whilst current temperature changes can be replicated, rainfall can be overestimated by up to $20 \%$ in sub-Saharan Africa and sea-surface temperatures (which have a significant effect on rainfall patterns) can be overestimated by $1-3{ }^{\circ} \mathrm{C}$ by current GCMs ${ }^{4}$.

Modelling climate systems within Africa is particularly difficult due to the lack of observed data from the continent and the complexity of the continent's climate. Rainfall patterns are dominated by seasonal migration of the tropical rain belts. Small shifts in the position or the timing of the movements of these rain belts will result in large local changes in rainfall. Being able to simulate such processes within climate models is essential for the accurate predictions of the effect of global climate change in Africa. However, as yet, less than half of the climate projections agree on what rainfall change can be expected with seasonal movement of the rain belts. The uncertainty is greatest within the western Sahel $\left(10-18^{\circ} \mathrm{N}\right.$, and $\left.17.5-20^{\circ} \mathrm{E}\right)$ with some GCMs predicting significant drying whilst others simulate a progressive wetting with an expansion of vegetation into the Sahara ${ }^{8}$. New GCM models are being developed, but it is unlikely that climate models will have the capacity to model accurately the required level of climatic complexity for reliable climate projections in the near future.

\subsection{Projected Climate Change in Africa}

Despite the uncertainties, climate change, both globally and within Africa, is likely to represent an intensification of present climatic variability rather than a catastrophic change in the mean climate state. Bestestimate projections of the IPCC Fourth Assessment Report indicate that the global mean temperature will rise between $1.8^{\circ} \mathrm{C}$ under scenario B1 and up to $4{ }^{\circ} \mathrm{C}$ under scenario A1F1 by 2100 , compared with the $1980-1999$ period ${ }^{15,4}$. Warming over land will be greater than the global mean temperature rise, due to less water availability for evaporative cooling and the smaller thermal inertia of the atmosphere as compared to the oceans ${ }^{4}$. As a result of this effect and changes to sea surface temperatures, atmospheric circulation and land-use 
patterns, the near-surface temperature rise in Africa for the same period is projected to be $3-4{ }^{\circ} \mathrm{C}$ (roughly 1.5 times the global mean response) ${ }^{8}$ - see Figure 5 .
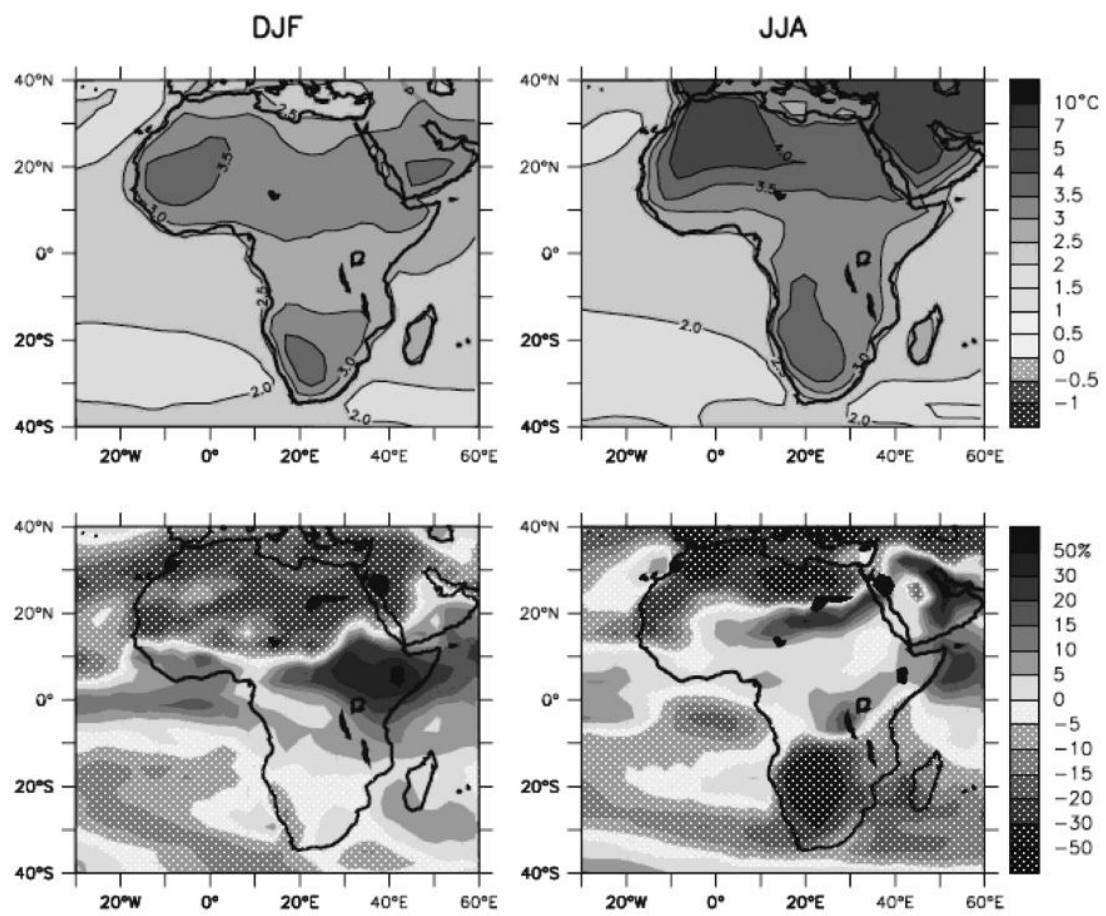

(Christensen et al. $2007^{23}$ ).

Figure 5 - Most likely temperature and precipitation changes modelled within Africa within winter (left) and summer (right) months. DJF refers to months December, January, February, whilst JJA refers to the months June, July, August. Temperature changes are show in the upper panel in degrees Celsius, whilst the predicted percentage change to rainfall is shown in the lower panels.

A warmer global climate will result in many other climatic changes:

- Warmer atmospheric conditions will lead to an intensification of the hydrological system, so that rainfall events will be of greater intensity and of greater spatial and temporal variability ${ }^{8}$. Extreme events, such as tropical storms, floods and droughts are projected to increase in both frequency and intensity.

- Seasonal rainfall patterns in Africa, which are presently dominated by the seasonal migration of the tropical rain belts, will be exaggerated, with small shifts in the position of these rain belts resulting in large local changes in rainfall ${ }^{9}$. However, there is considerable uncertainty within the GCMs as to how rainfall is likely to change in the future.

- Overall, GCMs generally predict rainfall to decrease by up to $20 \%$ in northern Africa, to decrease by up to $30 \%$ in southern Africa, and to increase by c. $7 \%$ within central and eastern Africa ${ }^{8,4}$ - see Figure 5. Uncertainty is greatest for the western Sahel $\left(10-18^{\circ} \mathrm{N}\right.$, and $\left.17.5-20^{\circ} \mathrm{E}\right)$, with some GCMs predicting significant drying and others simulating a progressive wetting, with an expansion of vegetation into the Sahara ${ }^{8}$. 
- More than half of the predicted reduction in rainfall in northern and southern Africa is modelled to occur in the northern hemisphere spring as a result of delay in summer rainfall ${ }^{8}$.

\subsection{Climate Science since the IPCC Fourth Assessment: $4{ }^{\circ} \mathrm{C}$ Possibilities}

Although the IPCC Fourth Assessment Report is still regarded as the authoritative work on climate change, observed data since 2000 indicates that the IPCC scenarios of future emissions and 'likely' climate change are conservative ${ }^{16,13}$. The Fourth Assessment Report concluded that a mean global temperature rise of $1.8{ }^{\circ} \mathrm{C}$ was most likely, but population growth, intensification of economic globalisation and a failure to decarbonise global energy sources has meant fossil-fuel emissions have consistently matched those predicted by the 'worst-case' (A1F1) scenario of the IPCCs Fourth Assessment ${ }^{7,17,18}$ - see Figure 6.

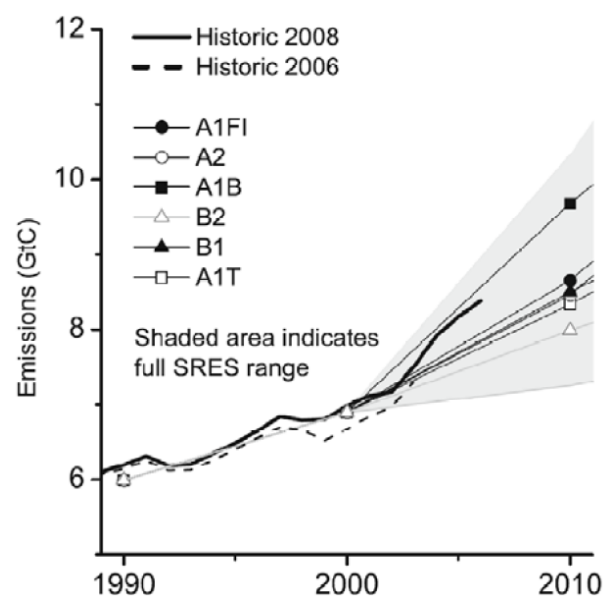

Source: Van Vuuren and Riahi $2008^{7}$.

Figure 6 - present trajectory of emissions (as Gigatons Carbon) since 2000 has consistently matched the worst-case emissions scenario of the IPCC Fourth Assessment Report. The shaded area indicates the range of emissions predicted by the IPCC in the Special Report on Emissions Scenarios (SRES) in the 4th Assessment Report.

Since 2000, fossil fuel emissions have increased at a rate of $3.4 \% \mathrm{yr}^{-1}$, compared with just $1.0 \% \mathrm{yr}^{-1}$ in the $1990 \mathrm{~s}^{19}$. Key climatic indicators, such as the rate of ice-sheet melt and global ocean temperature, have exceeded those predicted to be likely and sea-level is now expected to rise by more than $1 \mathrm{~m}$ by 2100 due to thermal expansion alone ( $0.5 \mathrm{~m}$ more than that predicted by the IPCC in 2007), and by up to a further metre due to current rates of melting of the Arctic and Greenland ice sheets ${ }^{16}$. There is also evidence to suggest that the land and ocean sinks of atmospheric $\mathrm{CO}_{2}$ are becoming weakened and not keeping up with current increases in $\mathrm{CO}_{2}$ emissions ${ }^{19,14}$. A weakening of $\mathrm{CO}_{2}$ sinks could lead to much greater warming from emission increases than observed at present ${ }^{19}$. 
Based on observational evidence since 2000, there is an emerging consensus that a global mean temperature rise of $2.4{ }^{\circ} \mathrm{C}$ is likely, regardless of any emissions cuts, and that a global mean temperature rise of $4{ }^{\circ} \mathrm{C}$ is more likely than not by $2100{ }^{19,16,6,7}$. Recent modelling work using the HadCAM GCM suite suggests a $4{ }^{\circ} \mathrm{C}$ rise in global mean temperature would result in a rise in near-surface temperatures in Africa of between 5.0 to $7.5^{\circ} \mathrm{C}$ by $2100^{20,21}$. Such a strong warming of the atmosphere would have a significant impact on processes in the hydrological system in Africa ${ }^{4}$ and it is increasingly thought that we need to prepare for greater climatic uncertainty, based on a $4{ }^{\circ} \mathrm{C}$ rise in global mean temperature. In response, the Fifth Assessment of climate change, due to be published by the IPCC in 2013, is to be based on a revised set of emissions scenarios which will include a wider range of possible future emissions ${ }^{22}$. The scenarios will also be generated using a more cause-and-effect approach, to enable better simulation of the feedbacks between increased emissions, potential climate change and adaptation ${ }^{22}$.

\subsection{Summary}

The IPCC Fourth Assessment of climate change is the most valid assessment to date, but the predictions of climate change are increasingly thought to be conservative. Despite the significant uncertainty still surrounding climate change projections, there is an emerging consensus based on observational evidence since 2000 that there will be a global mean temperature rise of $2.4{ }^{\circ} \mathrm{C}$ by 2100 , regardless of any future emissions cuts, and that adaption should now be based on a $4^{\circ} \mathrm{C}$ rise in global mean temperate. Key facets of climate change can be summarised as follows:

- Climate change, both globally and within Africa, is likely to represent an intensification of present climatic variability rather than a catastrophic change in mean climate state.

- It is highly likely that by 2100 near-surface temperatures will be $3-4{ }^{\circ} \mathrm{C}$ higher over Africa (possible 5$7.5^{\circ} \mathrm{C}$ ) and, even under the most conservative climate change prediction, global sea-level rise is likely to be more than 1 metre.

- Generally, rainfall is predicted to decrease by up to $20 \%$ in northern Africa, to decrease by up to $30 \%$ in southern Africa and to increase by c. 7\% within central and eastern Africa - see Figure 5. However, up to $90 \%$ of GCMs cannot accurately replicate current climatic conditions in Africa, so there is significant uncertainty in rainfall projections, particularly within the western Sahel where it is still unclear whether rainfall will increase or decrease.

- Warmer atmospheric conditions will lead to an intensification of the hydrological system, so that rainfall events will be of greater intensity and of much greater spatial and temporal variability.

- Climate modelling uncertainties are large in Africa. Up to 90\% of GCMs cannot accurately replicate past or present climatic conditions within sub-Saharan Africa, suggesting key climatic processes are being omitted from models.

\section{Impacts of Climate Change on Rural Water Supply in Africa}




\subsection{A Framework for Discussion}

Predicting the effects of climate change on rural water supplies in Africa is difficult, not least because of the considerable uncertainty in climate change predictions and the even greater uncertainty within derived hydrological models ${ }^{23}$. There are also large data and knowledge gaps in existing run-off and recharge processes within Africa ${ }^{24}$. To help deal with this level of uncertainty in climate science, it is useful to adopt a three-sided approach to examine how climate change is likely to affect rural water supplies, focusing on water availability, water use and the ability to access available water ${ }^{5}$. Ultimately it is the interplay between these three factors which will determine future water security in Africa ${ }^{3,5}$.

\subsection{Likely Impact of Climate Change on Available Water Resources}

\subsubsection{General}

Within a warmer climate, there will be higher evaporative demand, higher sea and land-surface temperatures and consequently existing climatic variability in Africa will be intensified, so that rainfall will occur in more intense events of higher spatial and temporal variability and dry periods will be both more prolonged and more frequent ${ }^{4,25}$. Whilst this climate change is highly likely, how it will translate to changes in effective rainfall and the partitioning of this effective rainfall between different water resources through altered patterns of surface run-off, soil moisture and groundwater recharge, is unclear ${ }^{26}$. Collectively, there are too many uncertainties, and the processes and feedback processes involved too complex for the effect of climate change on hydrological systems to be modelled adequately at present ${ }^{26}$. It is, therefore, very difficult to predict the likely impacts of climate change on rural water supplies from climate model projections. However, examining how the different water resources in Africa respond to existing climatic variability can provide an insight into the likely effects of climate change. Improved supplies generally rely on groundwater resources, whilst for unimproved supplies surface water and very shallow, perched groundwater ( $<10 \mathrm{~m}$ deep) resources are important.

\subsubsection{Surface Water Resources}

Surface water resources in Africa are already strongly seasonal and variability in river flow in most regions is marked as a result of present climatic variability ${ }^{27,28,29}$ - see Figures 7 and 8 . Superimposed on these seasonal variations are "natural" variations, in which drought and flood are already part of the existing hydrological system ${ }^{31}$. Increased intensity and irregularity of rainfall with future climate change will mean inter-annual variability of river flows is likely to increase, such that rivers will be increasingly seasonal and flashy. Flood events within the wet season may become more common and an increased proportion of 'available' surface water will be lost or redistributed in peak river discharges, reducing year-round access. 

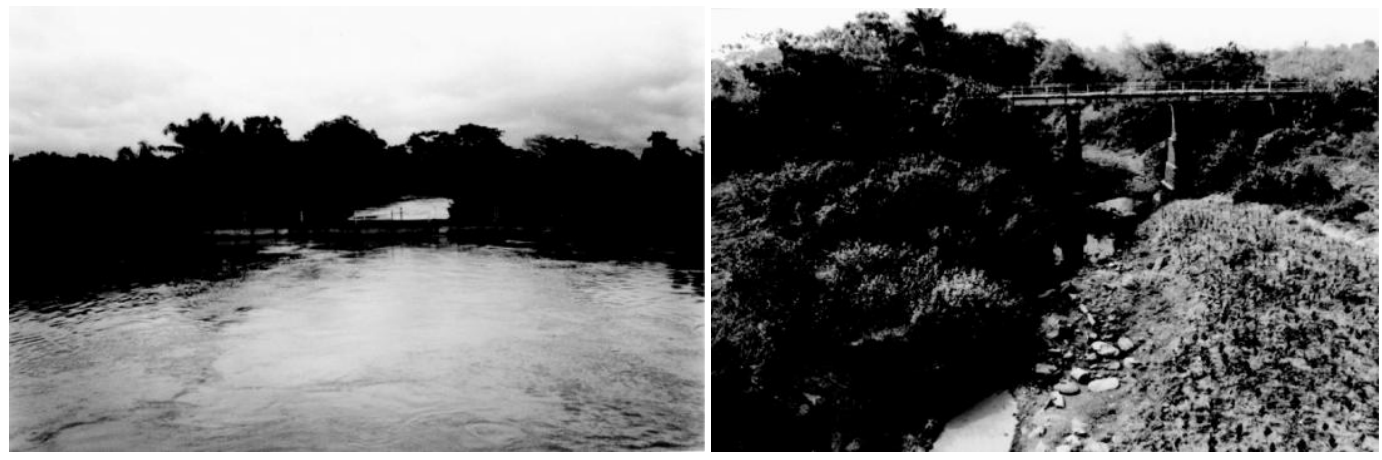

Figure 7 - Strong variability to surface water availability already exists in sub-Saharan Africa. Difference in seasonal flow of River Oju, SE Nigeria: mid-wet season (left), mid dry season 4 months later (right).

(a)

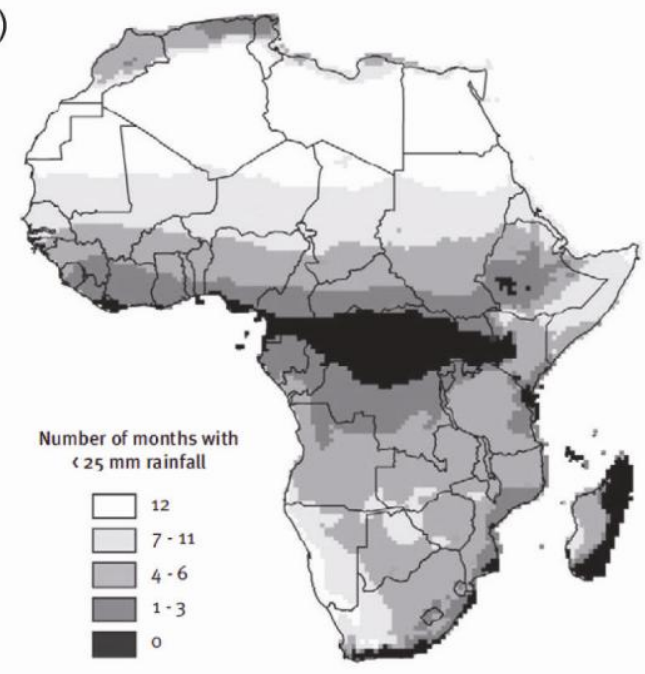

(c)

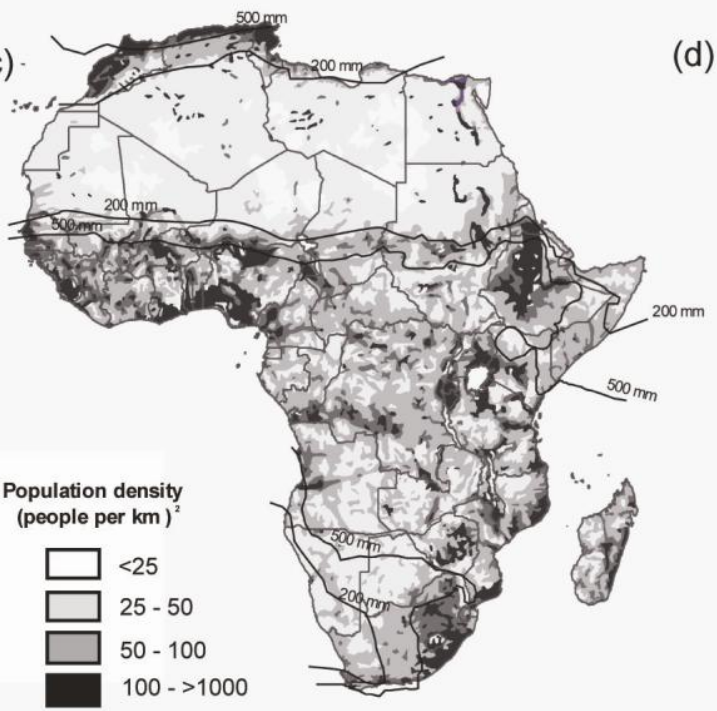

(b)

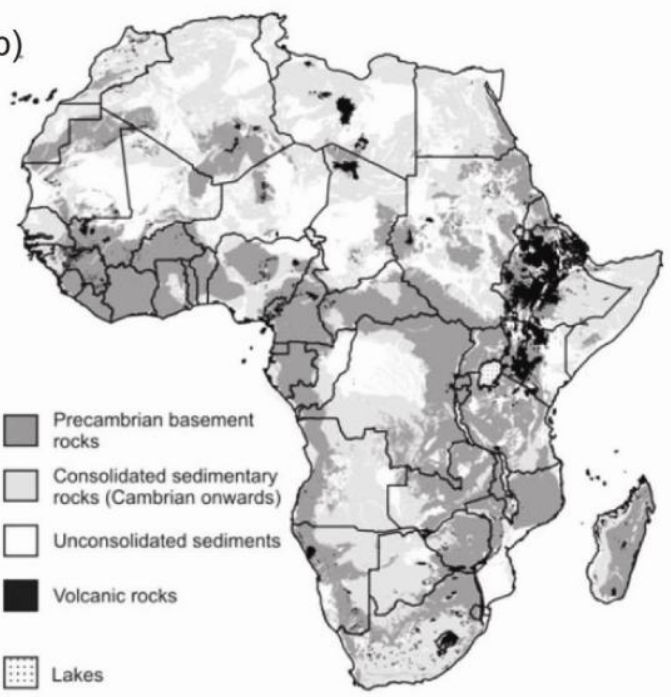

(d)

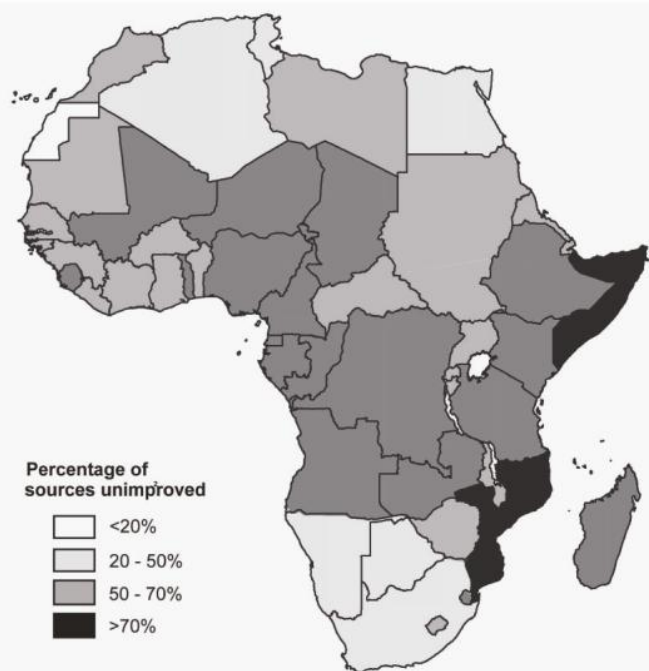

Figure 8 - Climatic and hydrogeological maps of Africa. Map (a) illustrates the average length of the dry season in Africa (1961-1996), calculated using data from New et al. $1999^{30}$; map (b) indicates the main hydrogeological environments of Africa ${ }^{3}$; map (c) displays the main rainfall-recharge zones relative to the population density in Africa ${ }^{3}$; and map (d) shows the percentage of unimproved supplies within rural Africa over the continent using data from the JMP $2008{ }^{1}$. 
In the long term, change to surface water availability will be entirely dependent on how changes in rainfall patterns and increased evaporative demand translate to shifts in soil moisture deficits and surface water run-off 8,26. At present, quantifying such changes is beyond present prediction capabilities, but it is highly likely that surface water resources will become increasingly unreliable ${ }^{32,8}$.

\subsubsection{Groundwater Resources}

Most improved water supplies in rural Africa depend on groundwater ${ }^{3}$. As rainfall and surface waters become less reliable, the demand on groundwater-based supplies is likely to increase further ${ }^{3}$. Unlike surface water, groundwater is less responsive to short-term climatic variability and will be buffered to the effects of climate change in the near-term as a result of the storage capacity of the aquifer. The potential long-term impact of climate change on the availability of groundwater is, however, largely unknown, not least because of the complexity of recharge processes in Africa, which are poorly constrained at present, even without the complications of climate change ${ }^{33,34}$.

\section{Recharge}

Climate change is likely to modify groundwater recharge patterns, as changes in precipitation and evaporation translate directly to shifts in soil moisture deficits and surface water run-off ${ }^{3,35}$. Increases in rainfall intensity and evaporative demand will, more likely than not, result in increased irregularity of groundwater recharge ${ }^{26}$. Recent modelling work within humid regions of Africa, has stressed the link between rainfall intensity and recharge, and it is possible that greater rainfall intensity predicted with climate change might in fact lead to increases in recharge by up to $50-200 \%{ }^{36,37,38}$. There is no simple, direct relationship between rainfall and recharge, and recharge patterns will additionally be affected by soil degradation and vegetation changes that are likely with increased climatic variability. Even though rainfall intensity is likely to increase in the future, soil degradation and vegetation changes might in fact mean more rainfall becomes surface run-off, so that recharge will decrease $36,39,40,41$. There is still, therefore, a large degree of uncertainty as to what the final effect of climate change will be on recharge patterns, particularly within semi-arid regions, as a result of the complexity of the processes.

\section{Aquifer Storage}

Recent studies of rural water use and the response of groundwater supplies have indicated that, even with reduced and more irregular recharge patterns, groundwater resources at depth (probably deeper than 10-20 m) in many aquifers will generally be of sufficient storage capacity to remain a secure water resource for the domestic water need in Africa. Groundwater-based domestic supplies require little recharge $(<10 \mathrm{~mm})$, as rural domestic water use is low (average hand pump yield is $5-10 \mathrm{~m}^{3} \mathrm{~d}^{-1}$ ) ${ }^{3,42,43}$. Based on these recharge values and some preliminary modelling work, MacDonald et al. (2009) ${ }^{3}$ suggest that it is low-storage aquifers in areas where annual rainfall is currently between 200 and $500 \mathrm{~mm}$ that are most at risk - see Figure 8. Although recharge processes are highly complex, the limited available data suggest that recharge becomes much less reliable at rainfall less than $500 \mathrm{~mm}$ per annum ${ }^{44,45,46}$. 
However, it is only improved water supplies which access deeper, more sustainable groundwater resources. Instead, the majority of the rural population relies on unimproved supplies which use shallow groundwater sources (generally less than $10 \mathrm{~m}$ deep) within deep soils - see Figure 8. This groundwater is often ephemeral and the soil layers are of much lower storage capacity than aquifers at depth; the shallow groundwater relies on frequent regular recharge for the resource to be sustainable ${ }^{3}$. During extended dry seasons under existing climatic variability, the shallow groundwater resource already often fails ${ }^{47}$ - see Figure 9. Increased rainfall variability predicted with climate change is likely to mean unimproved water supplies in low storage regolith (weathered soil material) aquifers could fail more often more of the time.
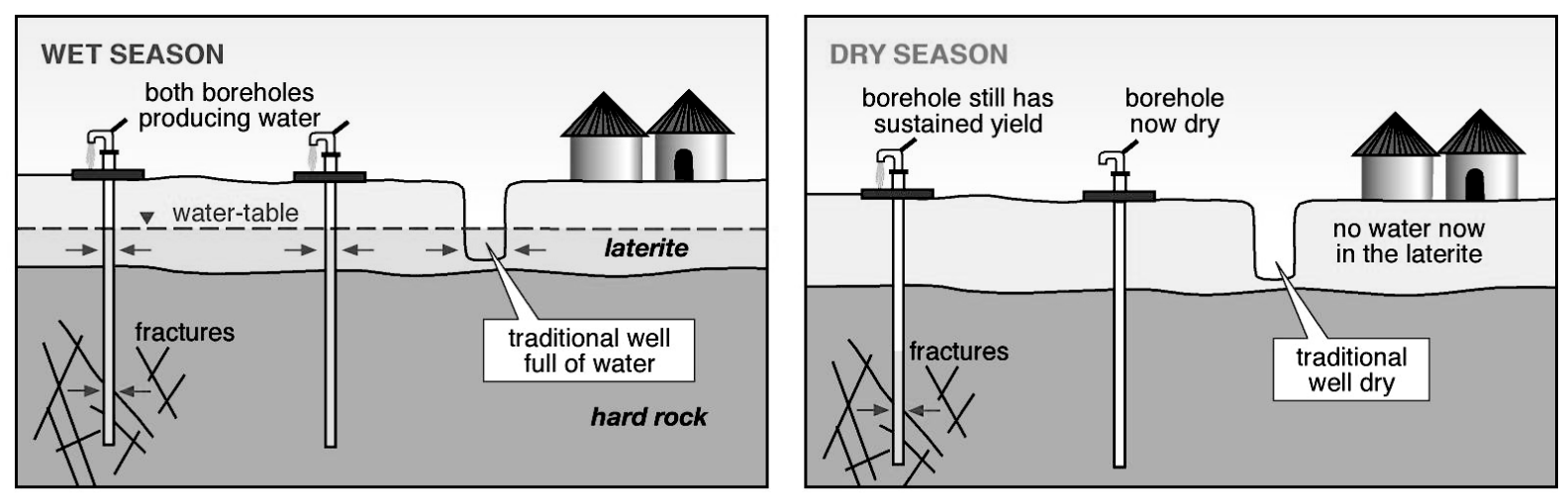

Figure 9 - The shallow, perched groundwater resource held within laterite soil often fails in the dry season, leading to the failure of unimproved water supplies ${ }^{53}$. In contrast, groundwater resources at depth (more than $20 \mathrm{~m}$ below ground surface) are modelled to be of sufficient storage capacity to support rural domestic water demand, based on a hand pump with a yield of $5 \mathrm{~m}^{3} \mathrm{~d}^{-1}$.

\section{Quality of Water Resources}

Even without climate change, there are significant threats to the quality of surface and shallow groundwater sources as a result of the lack of sanitation in rural Africa (less than $70 \%$ of the population has access to sanitation), the use of on-site sanitation and the growing use of fertilisers to increase crop yields ${ }^{1,48}$. Intense rainfall events can flush contamination from soil into rivers and groundwater. Once within groundwater, pathogenic contaminants can be transported significant distances (up to $1 \mathrm{~km}$ ) through the permeable regoliths whilst still virulent $48,49,50$. Within the wet season, high groundwater levels (often less than $10 \mathrm{~m}$ below ground surface) also mean pathogens (and other suspended contaminants) can enter shallow groundwater directly from the base of latrines and other conduits, making the shallow groundwater source highly vulnerable to contamination $^{3}$.

Climate change may exacerbate these existing water quality issues, so that the quality of surface water and shallow groundwater may be further impacted ${ }^{9,26}$. Increased flooding of latrines and unimproved sources could lead to a rise in diarrhoeal disease and infant mortality, and warmer water temperatures could lead to greater transmission of disease, for example ${ }^{51}$. Reduced functioning of water supplies during extended droughts could increase the burden of disease. In regions where surface water and groundwater recharge are projected to decrease, general inorganic water quality may also decrease due to the lower dilution capacity of the water resources ${ }^{26}$. However, predictions of how, and by how much, future water quantities will change are so 
uncertain that the potential for 'dilution' of the contaminant loading if water quantities were to increase cannot be relied upon to counter the flushing effect of more intense rainfall ${ }^{26}$.

\subsection{Access to Reliable Water Supplies}

Despite the considerable climatic variability which currently exists across much of Africa, the key determinant of existing water security in rural Africa is reliable access to water resources and not actual water resource availability itself $^{3,5}$. Research from Ghana, Nigeria, Malawi, South Africa and Ethiopia over the last 20 years provides some insights $53,54,5$. During droughts, unimproved supplies commonly fail as a result of high demands outstripping the limited capacity of unimproved sources ${ }^{43,55}$. The shallow groundwater resource, which unimproved supplies invariably access, requires regular annual recharge to ensure sustainable supply as a result of the low storage capacity of the regolith. Within dry seasons, the shallow regolith aquifers are often depleted and unimproved supplies fail. Only supplies which access larger, deeper groundwater resources (approximately $>20 \mathrm{~m}$ ) have been seen to be reliable - see Figure 9. Increasing access to these more secure groundwater resources could, therefore, go a significant way to mitigating existing and future water insecurity within rural Africa.

Improved supplies are not infallible, however, and they can fail in droughts when demand on improved supplies is high as a result of widespread failure of unimproved supplies ${ }^{5}$. Prolonged pumping can cause mechanical failure of hand pumps, especially if water-levels in boreholes have fallen and the pump lift is increased ${ }^{56}$. Mechanical failure is all the more likely if there has been a lack of pump maintenance ${ }^{43}$. Improved sources can therefore fail, even if sufficient water is regionally available for the high demand. This demand-driven failure of improved supplies is most likely in aquifers of limited permeability and storage and where there are few other improved sources locally to help disperse the demand across several improved wells ${ }^{43,55}$.

Increasing the resilience of rural water supplies to climate change should, therefore, be achieved by adopting actions already required to improve water security in Africa ${ }^{33,3}$. Increasing access to secure water supplies is a clear priority. But what technologies will be most reliable? Which will cope best with a changing climate? Table 1 outlines the main technology choices available in rural Africa. Technologies that rely on small streams and rivers, or ephemeral shallow groundwater resources, are likely to be the least reliable and are of greatest vulnerability to contamination. Those which abstract water from large surface-water sources or deeper groundwater are likely to be best able to cope with climate change ${ }^{56}$. 
Table 1 - The main water-supply technology choices for rural Africa. The effects of predicted climate change in Africa for each technology are outlined, alongside possible mitigation measures.

\begin{tabular}{|c|c|c|c|c|}
\hline Technology & Description & Climate risks & Possible impacts & Responses \\
\hline $\begin{array}{l}\text { Rainwater } \\
\text { harvesting }\end{array}$ & $\begin{array}{l}\text { Collecting water } \\
\text { from rainwater and } \\
\text { storing in tanks - } \\
\text { can be household or } \\
\text { community }\end{array}$ & $\begin{array}{l}\text { There may be fewer } \\
\text { rainy days - and } \\
\text { longer drought } \\
\text { periods. Rainfall } \\
\text { events may be more } \\
\text { intense }\end{array}$ & $\begin{array}{l}\text { Larger storage may be } \\
\text { required to provide storage } \\
\text { for the longer dry days. } \\
\text { Danger of damage and } \\
\text { contamination from } \\
\text { flooding }\end{array}$ & $\begin{array}{l}\text { Build in redundancy for potential } \\
\text { reduced rainfall and longer dry seasons. } \\
\text { Ensure protection against flooding }\end{array}$ \\
\hline $\begin{array}{l}\text { Reticulated } \\
\text { schemes from } \\
\text { small rivers and } \\
\text { dams }\end{array}$ & $\begin{array}{l}\text { Pumped schemes to } \\
\text { villages and small } \\
\text { towns based on } \\
\text { small dams or river } \\
\text { abstraction }\end{array}$ & $\begin{array}{l}\text { Changed seasonality } \\
\text { of runoff, peak flows } \\
\text { and sediment load. }\end{array}$ & $\begin{array}{l}\text { Lower and less certain } \\
\text { flows. Possible increased } \\
\text { sedimentation. } \\
\text { Dams may be filled with } \\
\text { sediment - possibility of } \\
\text { failure }\end{array}$ & $\begin{array}{l}\text { Design to a higher capacity. } \\
\text { Build in mechanisms for dealing with } \\
\text { increased sedimentation. } \\
\text { Conjunctive use of surface and } \\
\text { groundwater to increase adaptability to } \\
\text { change. }\end{array}$ \\
\hline $\begin{array}{l}\text { Shallow family } \\
\text { wells }\end{array}$ & $\begin{array}{l}\text { Wells less than } 10 \mathrm{~m} \\
\text { deep - dug by hand } \\
\text { and often unlined }\end{array}$ & $\begin{array}{l}\text { More intense rainfall, } \\
\text { longer dry season }\end{array}$ & $\begin{array}{l}\text { Increased contamination of } \\
\text { sources } \\
\text { More likely that sources } \\
\text { will fail }\end{array}$ & $\begin{array}{l}\text { Should generally not be promoted as } \\
\text { improved water supplies. }\end{array}$ \\
\hline $\begin{array}{l}\text { Improved hand- } \\
\text { dug wells }\end{array}$ & $\begin{array}{l}\text { Hand- dug wells, } \\
\text { often }>10 \text { m deep, } \\
\text { lined with concrete } \\
\text { and capped at the } \\
\text { surface }\end{array}$ & $\begin{array}{l}\text { More intense rainfall, } \\
\text { longer dry season }\end{array}$ & $\begin{array}{l}\text { Increased risk of } \\
\text { contamination. } \\
\text { More likely that sources } \\
\text { will fail }\end{array}$ & $\begin{array}{l}\text { Hand-dug wells should be tested at the } \\
\text { peak of a normal dry season. They } \\
\text { should be sited in productive parts of the } \\
\text { aquifer and deep enough to intersect } \\
\text { groundwater below } 10 \mathrm{~m} \text {. } \\
\text { There should be an emphasis on casing } \\
\text { out shallow layers and runoff. }\end{array}$ \\
\hline $\begin{array}{l}\text { Protected spring } \\
\text { supplies }\end{array}$ & $\begin{array}{l}\text { Perennial springs } \\
\text { where the source is } \\
\text { protected and piped } \\
\text { to a standpipe }\end{array}$ & $\begin{array}{l}\text { Longer dry season - } \\
\text { more intense rainfall }\end{array}$ & $\begin{array}{l}\text { Possibility of } \\
\text { contamination - } \\
\text { particularly if in more } \\
\text { urban setting. } \\
\text { Springs may be less } \\
\text { reliable in longer dry } \\
\text { seasons }\end{array}$ & $\begin{array}{l}\text { More thorough investigation of seasonal } \\
\text { spring flow and contamination pressures } \\
\text { in catchment. Build in greater } \\
\text { redundancy. }\end{array}$ \\
\hline Boreholes & $\begin{array}{l}\text { Boreholes, 20-60 m } \\
\text { deep, with hand- } \\
\text { pump mechanism to } \\
\text { abstract water }\end{array}$ & $\begin{array}{l}\text { Longer dry season - } \\
\text { more intense rainfall }\end{array}$ & $\begin{array}{l}\text { Higher demand within } \\
\text { extended dry seasons may } \\
\text { cause source failure and, in } \\
\text { some cases, depletion of } \\
\text { water resource. High } \\
\text { demand can lead to } \\
\text { mechanical failure. } \\
\text { Risk of supply } \\
\text { contamination from very } \\
\text { shallow layers of source } \\
\text { during intense rainfall. }\end{array}$ & $\begin{array}{l}\text { To improve reliability of water supply, } \\
\text { ensure boreholes are sited in most } \\
\text { productive part of aquifer and are of } \\
\text { higher storage capacity. It is also } \\
\text { important to improve maintenance of the } \\
\text { hand-pumps - particularly within the } \\
\text { dry season. } \\
\text { Ensure shallow layers of groundwater } \\
\text { source are cased out to prevent } \\
\text { contamination of the supply. }\end{array}$ \\
\hline $\begin{array}{l}\text { Large piped } \\
\text { schemes from } \\
\text { large dams and } \\
\text { rivers. }\end{array}$ & $\begin{array}{l}\text { Capital-intensive } \\
\text { schemes to large } \\
\text { towns and cities }\end{array}$ & $\begin{array}{l}\text { Increased demand in } \\
\text { cities. Changes in } \\
\text { runoff and } \\
\text { sedimentation }\end{array}$ & $\begin{array}{l}\text { Larger storage should be } \\
\text { able to cope with climate } \\
\text { fluctuations. } \\
\text { Large increase in demand } \\
\text { may lead to failure. }\end{array}$ & $\begin{array}{l}\text { Although this water resource may be } \\
\text { more resilient to climate change, effects } \\
\text { of demand and possibilities of reliability } \\
\text { may make it vulnerable. Consideration } \\
\text { should be given to conjunctive use, } \\
\text { backup and designing to cope with } \\
\text { higher demand. }\end{array}$ \\
\hline
\end{tabular}


In summary, increasing access to the most appropriate water resources could mitigate the effects of increased climatic variability; climate change need not necessarily lead to catastrophic, continent-wide failure of rural water supplies, as is too commonly portrayed in the media ${ }^{5}$. Several actions would help increase water security:

- Increasing water supply coverage to meet the Millennium Development Goals for water, reducing dependence on shallow unimproved sources.

- $\quad$ Targeting large reliable water resources, such as deeper groundwater.

- Matching the water supply technology to groundwater conditions and siting sources in the most productive parts of the aquifer.

- Maintaining water sources so that more are operational at the outset of drought periods.

- Ensuring water sources are protected from periodic flooding and contamination.

\subsection{Changing Water Demands}

Whilst climate change is significant and will undoubtedly affect the availability of some water resources in rural Africa, it is not happening in isolation and other pressures are likely to have a greater impact on water security over the next 50 years - most notably, population growth, land-use change and agriculture demand ${ }^{57}$. Unlike climate change, the prospects of demographic change in Africa in the $21^{\text {st }}$ Century are known with some certainty ${ }^{57}$. Africa has the highest population growth rate in the world at present (1.6-3.1\% per year) and the population is set to increase from 900 million in 2009 to approximately 2 billion by $2100^{58,59}$. The increase in domestic and agricultural demand for freshwater which will follow this population growth are likely to outstrip any effects of climate change on water security in Africa ${ }^{3,57,60}$.

In rural Africa, where the population is dispersed, the increase in domestic water demand predicted with population growth is unlikely to pose a significant threat to the sustainability of renewable water resources, as long as the rural population remains dispersed and water demand limited to 20 litres per person per day ${ }^{57}$. It is estimated population growth in rural areas by the end of the $21^{\text {st }}$ Century will lead to an increase in water demand of less than $0.5 \mathrm{~mm}$ water a year across the continent; less than $1 \%$ of total annual recharge estimated to presently occur over Africa ${ }^{57}$. However, increased water demand in the agricultural sector to meet rising food demands with population growth will place a much greater demand on available water resources ${ }^{33,57}$. Overexploitation and widespread depletion of the groundwater resource could easily occur in the absence of careful management.

Future food security with predicted population growth can only be met with increased use of irrigation and careful water management ${ }^{57}$. Already, there are concerns about whether food production from rain-fed and irrigated systems can be increased to meet the growing food demand, and increased land degradation and more 
prolonged dry periods with climate change will only exacerbate current difficulties ${ }^{3}$. Indeed, it is estimated that climate change could cause rain-fed cereal yields to decrease by up to $50 \%^{8}$.

Increasing the level of irrigation within Africa could help increase food production, just as groundwater-fed irrigation has proved a viable way of increasing agricultural output to support rising demands in Asia. However, this development of groundwater was only possible in Asia because of the existence of extensive, productive aquifers (e.g. the deep sedimentary aquifer in Gujurat and the basaltic aquifers in Deccan) and the same development could not be supported by the lower-yielding aquifers of limited storage capacity which underlie $80 \%$ of Africa's land area ${ }^{56,35}$. Whilst the lower yielding aquifers in Africa are thought to represent a secure source of water for dispersed domestic water demands, the aquifers are of insufficient storage and permeability to be able to support very high domestic and agricultural water demands.

Consequently, intensive groundwater-based irrigation is unlikely to be an appropriate Africa-wide strategy, and even small-holder irrigation schemes in rural areas need to be managed carefully so as to ensure sustainable exploitation of the groundwater source ${ }^{56}$. Increasing groundwater abstraction ten-fold to meet agricultural demand near urban areas could threaten the sustainability of domestic water supplies and could lead to widespread over-exploitation - particularly in the more-productive aquifers where regional drawdown of groundwater-levels are more likely ${ }^{3}$. Indeed, in the higher-yielding sandstone and unconsolidated sedimentary aquifers in areas of north Africa, where groundwater development supports roughly $30 \%$ of agricultural production, agriculture is already mining non-renewable reserves and nearing the limit of expansion ${ }^{61}$.

\section{Summary}

Significant uncertainty still surrounds present climate projections. However, there is an emerging consensus, based on observational evidence since 2000 , that global mean temperature will rise by $2.4{ }^{\circ} \mathrm{C}$ by 2100 , regardless of any emission cuts, and that adaptation should now be based on a $4{ }^{\circ} \mathrm{C}$ rise in global mean temperature $^{7,16,19}$. One of the key uncertainties surrounding the impacts of a changing climate in Africa is the effect that it will have on the sustainability of rural water supplies. Of Africa's population of 900 million, roughly $60 \%$ live in rural areas and most (perhaps $80 \%$ ) rely on groundwater-based community or household supplies for domestic and other water needs. Understanding the impacts of climate change on groundwater resources is, therefore, of critical importance, yet is often ignored in development debates. Below are some of the key issues that need to be considered:

1. Those relying on unimproved water sources (300 million in rural Africa) are likely to be the most impacted by climate change. This is because unimproved sources often tap ephemeral water resources such as very shallow groundwater, ponds and small streams.

2. Improved rural water supplies in Africa are overwhelmingly dependent on groundwater and dependence is likely to increase as surface water resources become more unreliable. A key advantage of groundwaterbased supply is reliability, both for domestic and productive uses. 
3. Climate modelling uncertainties, combined with rapid socio-economic change, make predicting water resources in the future difficult. While there is good confidence in temperature projections, rainfall scenarios remain uncertain, as do impacts on groundwater recharge. Demand-side pressures on water resources are more clear cut and may dwarf the impacts of climate change.

4. Is there a future problem? Yes, but it is important to emphasise that climate change will not lead to the continent-wide failure of improved rural water sources. This is because groundwater-based domestic demand requires very little recharge. However, a significant minority of people could be affected if rainfall declines in those areas with limited groundwater storage, especially if the frequency of droughts increases.

5. In most areas, the key determinant of water security will continue to be access rather than availability. Extending access, and ensuring that targeting and technology decisions are informed by an understanding of groundwater conditions, is becoming increasingly important.

6. Accelerating groundwater development for irrigation could increase food production, raise rural incomes and reduce vulnerability. However, ad hoc development could threaten domestic supplies and, in some areas, lead to groundwater depletion. 


\section{References}

${ }^{1}$ JMP Global water supply and sanitation 2008 report. Joint Monitoring Programme WHO/UNICEF. World Health Organisation, Geneva, 2008.

${ }^{2}$ A. M. MacDonald, J. Davies, R. C. Calow and J. Chilton, "Developing groundwater: a guide for rural water supply” ITDG Publishing, Rugby, UK, 2005, 358pp

${ }^{3}$ A. M. MacDonald, R. C. Calow, D. M. J. MacDonald, G. W. Darling and B. É. Ó Dochartaigh, Hydrol. Sci. J., 2009, 54, 690-703.

${ }^{4}$ G. A. Meehl, T.F. Stocker, W. D. Collins, P. Friedlingstein, A. T. Gaye, J. M. Gregory, A. Kitoh, R. Knutti, J.M. Murphy, A. Noda, S.C.B. Raper, I.G. Watterson, A.J. Weaver and Z.-C. Zhao, "Global Climate Projections" in Climate Change 2007: The Physical Science Basis. Contribution of Working Group I to the Fourth Assessment Report of the Intergovernmental Panel on Climate Change, S. Solomon, D. Qin, M. Manning, Z. Chen, M. Marquis, K. B. Averyt, M. Tignor and H. L. Miller (eds), Cambridge University Press, Cambridge, United Kingdom and New York, NY, USA. 2007.

${ }^{5}$ R. C. Calow, A. M. MacDonald, A. L. Nicol and N. S. Robins, Ground Water, 2010, 48, 246-256.

${ }^{6}$ V. Ramanthan and Y. Feng, Proceedings of the National Academy of Sciences (PNAS), 2008, 105, 38, $14245-$ 14250.

${ }^{7}$ D. P. Van Vuuren and K. Riahi, Climate change, 2008, 91, 237-248.

${ }^{8}$ M. Boko, I. Niang, A. Nyong, C. Vogel, A. Githeko, M. Medany, B. Osman-Elasha, R. Tabo and P. Yanda, "Africa" in Climate Change 2007: Impacts, Adaptation and Vulnerability. Contribution of Working Group II to the Fourth Assessment Report of the Intergovernmental Panel on Climate Change, M. L. Parry, O. F. Canziani, J. P. Palutikof, P. J. van der Linden \& C. E. Hanson (eds), Cambridge University Press, Cambridge UK, 2007, 433-467.

${ }^{9}$ B. Bates, Z. Kundzewicz, S. Wu and J. Palutikof (eds), IPCC: Climate change and water, IPCC Working Group II, Technical Paper of the Intergovernmental Panel on Climate Change, IPCC Secretariat, Geneva, 2007, 210 pp.

${ }^{10}$ N. Nakicenovic, J. Alcamo, G. Davis, B. de Vries, J. Fenhann, S. Gaffin, K. Gregory, A. Grübler, T. Yong Jung, T. Kram, E. L. La Rovere, L. Michaelis, S. Mori, T. Morita, W. Pepper, H. Pitcher, L. Price, K. Riahi, A. Roehrl, H-H. Rogner, A. Sankovski, M. Schlesinger, P. Shukla, S. Smith, R. Swart, S. van Rooijen, N. Victor, N. and Z. Dadi, IPCC Special Report on emissions scenarios, A Special Report of IPCC Working Group III, 2000.

${ }^{11}$ N. W. Arnell, Global Environ Chang, 2004, 14(1), 31-52.

${ }^{12}$ D. A. Randall, S. Wood, R. Bony, T. Colman, J. Fichefet, V. Fyfe, A. Kattsov, J. Shukla, J. Srinivasan, R. J. Stouffer, A. Sumi and K.E. Taylor, "Climate Models and Their Evaluation" in "Climate Change 2007: The Physical Science Basis." Contribution of Working Group I to the Fourth Assessment Report of the Intergovernmental Panel on Climate Change, S. Solomon, D. Qin, M. Manning, Z. Chen, M. Marquis, K. B. Averyt, M.Tignor and H. L. Miller (eds),, 2007, Cambridge University Press, Cambridge, United Kingdom and New York, NY, USA.

${ }^{13}$ M. Meinshausen, N. Meinshausen, W. Hare, S. C. B. Raper, K. Frieler, R. Knutti, D. J. Frame and M. R. Allen, Nature, 2009, 458, 30, 1158-1163.

${ }^{14}$ P. Friedlingstein, P. Cox, R. Betts, L. Bopp, W. von Bloh, V. Brovkin, S. Cadule, M. Doney, M. Eby, I. Fung, J. Bala, J. John, C. Jones, F. Joos, T. Kato, M. Kawamiya, W. Knorr, K. Lindsay, D. Matthews, T. Raddatz,. P. Rayner, C. Reick, E. Roeckner, K-G. Schnitzler, R. Schnur, K. Strassmann, A. J. Weaver, C. Yoshhikawa and N. Zeng, Journal of Climate, American Meterological Society,2006, 19, 3337-3353.

${ }^{15}$ M. L. Parry, O. F. Canziani, P. Palutikof, P. J. van der Linden and C. E. Hanson (eds), "Climate Change 2007: Impacts, Adaptation and Vulnerability". Contribution of Working Group II to the Fourth Assessment Report of the IPCC, Cambridge University Press, Cambridge, UK, 2007.

${ }^{16}$ K. Richardson, W. Steffen, H. J. Schnellnhuber, J. Alcamo, T. Barker, D. M. Kammen, R. Leemans, R. Liverman, M. Munasinge, B. Osman-Elasha, N. Stern and O. Waever, International Scientific Congress Synthesis Report, Climate Change, Global Risks, Challenges and Decisions, Copenhagen 2009, Copenhagen University Press. 2009. 
${ }^{17}$ M. R. Raupach, G. Marland, P. Ciais, C. Le Quere, J. G. Canadell, G. Klepper and C. B. Field, Proceedings of the National Academy of Sciences (PNAS), 2007, 104, 24, 10288.

${ }^{18}$ R. K. Pachauri and A. Reisinger (eds), Contribution of Working Groups I, II and III to the Fourth Assessment Report of the Intergovernmental Panel on Climate Change, IPCC Climate Change 2007: Synthesis Report, 2007.

${ }^{19}$ C. Le Quéré, M. R. Raupach, J. G. Canadell, G. Marland, L. Bopp, P. Ciais, T. J. Conway, S. C. Doney, R. A. Feely, P. Foster, P. Friedlingstein, K. Gurney, R. A. Houghton, J. I. House, C. Huntingford, P. E. Levy, M. R. Lomas, J. Majkut, N. Metzl, P. E. Ometto, G. P. Peters, C. I. Prentice, J. T. Randerson, S. W. Running, J. L. Sarmiento, U. Schuster, S. Sitch, T. Takahashi, N. Viovy, G. R. van der Werf and F. I. Woodward, Nature Geoscience, 2009, 2, 831-836.

${ }^{20}$ N. W. Arnell, "Climate change and water resources: a global perspective”. In H. J. Schellnhuber, W. Cramer, N. Nakicenovic, T. Wigley and G. Yohe (eds), Cambridge University Press, Cambridge, 2006, 167-175.

${ }^{21}$ D. P. Van Vuuren, M. Meinshausen, G-K. Plattner, F. Joos, K. M. Strassmann, S. J. Smith, T. M. Wigley, S. C. B. Raper, K. Riahi, F. de la Chesnaye, M. G. J. den Elzen, J. Fujino, K. Jiang, N. Nakicenovic, S. Paltsev and J. M. Reilly, Proceedings of the National Academy of Sciences (PNAS), 2009, 105, 40, 15258-15262.

${ }^{22}$ R. Moss, M. Babiker, S. Brinkman, E. Calvo, T. Carter, J. Edmonds, T. Elgizouli, S. Emori, L. Erda, K. Hibbard, R. Jones, M. Kainuma, J. Kelleher, J. F. Lamarque, M. Manning, B. Matthews, J. Meehl, L. Meyer, J. Mitchell, N. Nakicenovic, B. O’Neill, R. Pichs, K. Riahi, S. Rose, P. Runci, R. Stouffer, D. van Vuuren, J. Weyant, T. Wilbanks, J. P. van Ypersele and M. Zurek, "Towards New Scenarios for Analysis of Emissions, Climate Change, Impacts, and Response Strategies.” Technical Summary. Intergovernmental Panel on Climate Change, Geneva, 2008, 25 pp.

${ }^{23}$ J. H. Christensen, B. Hewitson, A. Busuioc, A. Chen, X. Gao, I. Held, R. Jones, R. K. Kolli, W.-T. Kwon, R. Laprise, V. Magaña Rueda, L. Mearns, C. G. Menéndez, J. Räisänen, A. Rinke, A. Sarr and P. Whetton, "Regional Climate Projections" in Climate Change 2007: The Physical Science Basis. Contribution of Working Group I to the Fourth Assessment Report of the Intergovernmental Panel on Climate Change, S. Solomon, D. Qin, M. Manning, Z. Chen, M. Marquis, K.B. Averyt, M. Tignor and H.L. Miller (eds), Cambridge University Press, Cambridge, United Kingdom and New York, NY, USA, 2007.

${ }^{24}$ S. M. A. Adelana, and A. M. MacDonald, in Applied Groundwater Studies in Africa, IAH Selected Papers on Hydrogeology, 13, CRC Press, Balkema, Amsterdam, 2008, 1-7.

${ }^{25}$ N. W. Arnell, Hydrol. Earth Syst. Sci., 2003, 7(5), 619-641.

${ }^{26}$ Z. W. Kundzewicz, L. J. Mata, N. W. Arnell, P. Döll, P. Kabat, B. Jiménez, K. A. Miller, T. Oki, Z. Sen and I. A. Shiklomanov, "Freshwater resources and their management" in Climate Change 2007: Impacts, Adaptation and Vulnerability. Contribution of Working Group II to the Fourth Assessment Report of the Intergovernmental Panel on Climate Change, M. L. Parry, O. F. Canziani, J. P. Palutikof, P. J. van der Linden and C. E. Hanson (eds), Cambridge University Press, Cambridge, UK, 2007, 173-210.

${ }^{27}$ K. Tilahun, Water $S A, 2006,32 ; 3,429-435$.

${ }^{28}$ D. Conway, Global Environ Chang, 2005, 15, 2, 99-114.

${ }^{29}$ M. Hulme, Global Environ Chang, 2001, 11, 19-29.

${ }^{30}$ M. New, M. Hulme, and P. D. Jones, J. Climate, 1999, 12, 829-856.

31 D. Verschuren, K. R. Laird and B. F. Cumming, Nature, 2000, 403, 410-414.

${ }^{32}$ Z. W. Kundzewicz and P. Döll, Hydrol. Sci. J., 2009, 54, 665-675.

${ }^{33}$ R. G. Taylor, A. D. Koussis and C. Tindimugaya, Hydrol. Sci. J., 2009, 54, 655-664.

${ }^{34}$ P. Döll and K. Fiedler, Hydrol. Earth Syst. Sci., 2008, 12; 863-885.

${ }^{35}$ S. S. D. Foster, A. Tuinhof and H. Garduño, In: "Applied groundwater research in Africa” S. M. A. Adelana and A. M. MacDonald (eds), IAH Selected Papers in Hydrogeology 13, Taylor \& Francis, Amsterdam, 2008, 9-21.

${ }^{36}$ L. Mileham, R. G. Taylor, M. Todd, C. Tindimugaya and J. Thompson, Hydrol. Sci. J., 2009, 54, 727-738. 
${ }^{37}$ L. Mileham, R. G. Taylor, J. Thompson, M. Todd and C. Tindimugaya, J. Hydrol., 2008, 359, $46-58$.

${ }^{38}$ P. M. Nyenje and O. Batelaan, Hydrol. Sci. J., 2009, 54, 713-726.

${ }^{39}$ S. Solomon, D. Qin, M. Manning, M. Marquis, K. Averyt, M. B. M. Tignor, H. Leroy Miller and Z. Chen, (eds), Climate Change 2007: The Physical Science Basis, Contribution of Working Group I to the Fourth Assessment Report of the IPCC, Cambridge University Press, 2007.

${ }^{40}$ B. R. Scanlon, K. E. Keese, A. L. Flint, L. E. Flint, C. B. Gaye, W. M. Edmunds and I. Simmers, Hydrol. Processes, 2006, 19, 3285-3298.

${ }^{41}$ P. Döll and M. Flöerke, “Global-Scale estimation of Diffuse Groundwater Recharge”, Frankfurt Hydrology Paper 03, Institute of Physical Geography, Frankfurt University, Frankfurt am Main, Germany, 2008.

${ }^{42}$ R. C. Carter and A. G. Alkali, Q. J. Eng. Geol., 1996, 29, 341-356.

${ }^{43}$ A. M. MacDonald, J. A. Barker and J. Davies, Hydrogeol. J., 2008, 16, 1065-1075

${ }^{44}$ J. J. De Vries and I. Simmers, Hydrogeol. J., 2002, 10, 5-17.

${ }^{45}$ W. M. Edmunds in “Applied groundwater research in Africa”, S. M. A. Adelana and A. M. MacDonald, IAH Selected Papers in Hydrogeology, Taylor \& Francis, Amsterdam, 2008, 13, 305-322.

${ }^{46}$ V. H. M. Eilers, R. C. Carter and K. R. Rushton, Geoderma, 2007, 140, 119-131.

${ }^{47}$ K. Walraevens, I. Vandecasteele, K. Martens, J. Nyssen, J. Moeyersons, T. Gebreyohannes, F. De Smedt, J. Poesen, J. Deckers and M. Van Camp, Hydrol. Sci. J., 2009, 54; 690-703.

${ }^{48}$ M. Pritchard, T. Mkandawire and J. G. O’Neill, Phys. Chem. Earth, 2008, doi:10.1016/j.pce.2008.06.036.

${ }^{49}$ R. G. Taylor, C. Tindimugaya, J. Barker, D. Macdonald and R. Kulabako, Ground Water, 2010, 48, $284-294$.

${ }^{50}$ S. M. A. Adelana, T. A. Abiye, D. C. W. Nkhuwa, C. Tindimugaya and M. S. Oga in "Applied groundwater research in Africa", S. M. A. Adelana and A. M. MacDonald (eds), IAH Selected Papers in Hydrogeology, Taylor \& Francis, Amsterdam, 2008, 13, 1-7.

${ }^{51}$ A. Costello, M. Abbas, A. Allen, S. Ball, S. Bell, R. Bellamy, S. Friel, N. Groce, A. Johnson, M. Kett, M. Lee, C. Levy, M. Maslin, D. McCoy, B. McGuire, H. Montgomery, D. Napier, C. Pagel, J. Patel, J. A. Puppim de Oliveira, N. Redclift, H. Rees, D. Rogger, J. Scott, J. Stephenson, J. Twigg, J. Wolff and C. Patterson, Lancet, 2009, 373; 1693-1733.

${ }^{52}$ R. V. Cruz, H. Harasawa, M. Lal, S. Wu, Y. Anokhin, B. Punsalmaa, Y. Honda, M. Jafari, C. Li and N. Huu Ninh in Climate Change 2007: Impacts, Adaptation and Vulnerability. Contribution of Working Group II to the Fourth Assessment Report of the Intergovernmental Panel on Climate Change, M. L. Parry, O. F. Canziani, J. P. Palutikof, P. J. van der Linden and C. E. Hanson (eds), Cambridge University Press, Cambridge, UK, 2007, 469-506.

${ }^{53}$ R. C. Calow, N. S. Robins, A. M. MacDonald, D. M. J. MacDonald, B. R. Gibbs, W. R. G. Orpen, P. Mtembezeka, A. J. Andrews and S. O. Appiah, International Journal of Water Resources Development, 1997, 13, 2, 241-261.

${ }^{54}$ R. C. Calow, A. M. MacDonald, A. Nicol, N. Robins and S. Kebebe, "The Struggle for Water: drought, water security and rural livelihoods", British Geological Survey Commissioned Report, 2006, CR/02/226N.

${ }^{55}$ E. P. Wright in "The Hydrogeology of Crystalline Basement Aquifers in Africa" E. P. Wright and W. Burgess, Geological Society London Special Publications, 1992, 6, 1-27.

${ }^{56}$ R. C. Calow and A. M. MacDonald, Overseas Development Institute (ODI) Background Note, March 2009.

${ }^{57}$ R. C. Carter and A. Parker, Hydrol. Sci. J., 2009, 54, 676-689.

${ }^{58}$ UN (United Nations) Population Division of the Department of Economic and Social Affairs of the United Nations Secretariat. World Population Prospects: the 2006 revision and World Urbanisation Prospects: the 2005 revision, 2007.

${ }^{59}$ R. C. Carter and J. E. Bevan in "Applied groundwater research in Africa", S. M. A. Adelana and A. M. MacDonald (eds), IAH Selected Papers in Hydrogeology, Taylor \& Francis, Amsterdam, 2008, 13, 25-42.

${ }^{60}$ C. J. Vörösmarty, P. Green, J. Salisbury and R. B. Lammers, Science, 2000, 289, 284-288. 
${ }^{61}$ W. Gossel, A. M. Sefelnasr, P. Wycisk and A. M. Ebraheem in "Applied groundwater research in Africa", S. M. A. Adelana and A. M. MacDonald (eds), IAH Selected Papers in Hydrogeology, Taylor \& Francis, Amsterdam, 2008, 13, 43-65. 